\title{
EFFECTS OF THE VADOSE ZONE ON GROUNDWATER FLOW AND SOLUTE TRANSPORT CHARACTERISTICS IN MOUNTAINOUS KARST AQUIFERS - THE CASE OF THE JAVORNIKI-SNEŽNIK MASSIF (SW SLOVENIA)
}

\author{
VPLIVI NEZASIČENE CONE NA ZNAČILNOSTI TOKA \\ PODZEMNE VODE IN PRENOSA TOPNIH SNOVI V GORSKIH \\ KRAŠKIH VODONOSNIKIH - PRIMER JAVORNIŠKO - \\ SNEŽNIŠKEGA MASIVA (JZ SLOVENIJA)
}

\author{
Metka PETRIČ ${ }^{1}$, Janja KOGOVŠEK ${ }^{1} \&$ Nataša RAVBAR ${ }^{1}$
}

\begin{abstract}
UDC 556.34(497.471)

Metka Petrič, Janja Kogovšek \& Nataša Ravbar: Effects of the vadose zone on groundwater flow and solute transport characteristics in mountainous karst aquifers - the case of the Javorniki-Snežnik massif (SW Slovenia)

Tracer tests are rarely applied in mountainous karst aquifers due to difficult or limited basic data acquisition, problems of access and expected strong tailing effects in tracer breakthrough. They are, however, a straightforward method for learning about the characteristics of underground water flow. The main aim of this study was to better understand the processes of flow and storage in the karst aquifer and its unsaturated (vadose) zone, which is several hundreds of metres thick. A tracer test was conducted with injection from the surface into a shaft in the central part of the aquifer. The results were compared to a previous tracer test with similar injection characteristics (the same tracer, injection into shaft vs karren) but with a significantly different vadose zone thickness. For this purpose, direct information obtained through tracer breakthrough curves analysis was modified in accordance with the distance factor, normalised as a function of tracer mass injected, and expressed as a residence time distribution. A conceptual model of flow and transport duality through the karst system was elaborated: part of the tracer flows rapidly through the primary drainage channels, while the other part is predominantly characterised by prolonged retention in less permeable zones. The results obtained support the idea that the thickness of the vadose zone has a very strong influence on residence times and dispersion. The subsequent outflow of the tracer and its detection greatly depend on the meteorological conditions. Our study suggests that the greater the thickness
\end{abstract}

Izvleček

UDK 556.34(497.471)

Metka Petrič, Janja Kogovšek \& Nataša Ravbar: Vplivi nezasičene cone na značilnosti toka podzemne vode in prenosa topnih snovi $v$ gorskih kraških vodonosnikih - primer Javorniško - Snežniškega masiva (JZ Slovenija)

Sledilni poskusi sodijo med metode, ki neposredno prikazujejo značilnosti toka podzemne vode. Zaradi oteženih ali omejenih dostopov do osnovnih podatkov, zahtevnosti terenskega dela in pričakovanega dolgotrajnega podaljšanja pojavljanja sledila se sledilni poskusi v gorskih kraških vodonosnikih redko izvajajo. Glavni namen te študije je bil boljše razumevanje procesov toka in skladiščenja $\mathrm{v}$ kraškem vodonosniku in njegovi nezasičeni (vadozni) coni, ki je lahko debela več sto metrov. Opravljen je bil sledilni poskus $\mathrm{v}$ osrednjem delu vodonosnika $\mathrm{z}$ injiciranjem v brezno. Rezultate smo primerjali s preteklim sledilnim poskusom s podobnimi lastnostmi injiciranja (enako sledilo, injiciranje $\mathrm{v}$ brezno oz. škraplje) toda s precejšnjo razliko $\mathrm{v}$ debelini vadozne cone. $\mathrm{V}$ ta namen so bile neposredne informacije, pridobljene $\mathrm{z}$ analizo sledilne krivulje, spremenjene $\mathrm{v}$ skladu $\mathrm{s}$ faktorjem razdalje, normalizirane kot funkcija količine uporabljenega sledila in izražene kot porazdelitev zadrževalnega časa. Izdelan je bil konceptualni model dvojnosti toka in prenosa topnih snovi skozi kraški sistem: del sledila se pretaka hitro skozi primarne drenažne kanale, medtem ko je za del tega značilno podaljšano zadrževanje $\mathrm{v}$ manj prepustnih območjih. Dobljeni rezultati podpirajo trditev, da debelina vadozne cone močno vpliva na zadrževalne čase in disperzijo. Poznejši odtok sledila in njegovo zaznavanje sta $\mathrm{v}$ veliki meri odvisna od meteoroloških razmer. Naša študija kaže, da je $\mathrm{z}$ večjo debelino vadozne cone njena zaščitna funkcija večja. Poleg tega je

\footnotetext{
${ }^{1}$ Karst Research Institute ZRC SAZU, Titov trg 2, SI-6230 Postojna, Slovenia and UNESCO Chair on Karst Education, University of Nova Gorica, Glavni trg 8, SI-5271 Vipava, Slovenia, e-mails: petric@zrc-sazu.si, natasa.ravbar@zrc-sazu.si, janja.kogovsek@ guest.arnes.si
}

Received/Prejeto: 25.05.2017 
of the vadose zone, the better its protective function. In addition, the study was also relevant from the regional perspective, in that it enabled us to identify more closely the location of the Adriatic-Black Sea watershed.

Key words: karst hydrogeology, tracer test, unsaturated zone, conceptual model, groundwater flow and storage, source protection. bila študija pomembna tudi $\mathrm{z}$ regionalnega vidika, saj nam je omogočila, da natančneje opredelimo jadransko-črnomorsko razvodnico.

Ključne besede: kraška hidrogeologija, sledilni poskus, nezasičena cona, konceptualni model, tok in skladiščenje podzemne vode, zaščita vodnih virov.

\section{INTRODUCTION}

Aquifers of mountainous karst and high karst plateaus supply manifold ecosystem services such as regional water budgets and freshwater supply, as well as supporting the rich and unique biodiversity of the underground water ecosystem. These aquifers, which are also headwater catchments, are increasingly threatened by numerous environmental problems such as global climate change, contamination, overuse and environmental degradation. To better protect and manage mountain karst resources, a deepening of knowledge about flow and storage mechanisms is necessary.

The behaviour of high karst plateaus and mountainous karst aquifers is poorly known, especially as regards characteristics of flow in the unsaturated (vadose) zone (Maloszewski et al. 2002; Mudarra \& Andreo 2011; Turk et al. 2015). Such aquifers usually cover an area of several tens or hundreds of $\mathrm{km}^{2}$ and have a complex hydrogeological structure. Recharge and subsurface flow mechanisms are conditioned by orography, meteorological conditions (i.e., strong snowmelt or precipitation events), vegetation cover and hydraulic gradients, as well as by the geological and structural context (Kogovšek \& Petrič 2004; Becker 2005; Müller et al. 2013). Groundwater flow is often dominated by an unsaturated zone that is several hundreds of metres thick, where extremely heterogeneous flow and storage processes prevail, often controlled by geological structure and tectonics (Lastennet \& Mudry 1997; Simsek et al. 2008; Goldscheider \& Neukum 2010; Turk et al. 2013). Flow processes are highly dependent on respective hydrological conditions causing groundwater fluctuations of several tens of metres and variations of flow velocity by several orders of magnitude. Consequently, the watershed boundaries and flow directions are variable and often very difficult to determine (Ravbar et al. 2011; Stevanovic et al. 2016).

In recent years, infiltration, flow and transport through karst aquifers has been thoroughly studied using various methods and techniques including natural and artificial tracers observed at cave drips or at aquifer outlets, and modelling (e.g., Emblanch et al. 2003; Perrin et al. 2003; Birk et al. 2004; Pronk et al. 2009; Doummar et al. 2012; Kogovšek \& Petrič 2014; Kübeck et al. 2013; Mudarra et al. 2014; Biondić et al. 2016; Fehér et al. 2016; Kaufmann et al. 2017). These studies are very important, since they all contribute to better understanding of the aquifer's intrinsic properties, which is a prerequisite for proper interpretation and prediction of their behaviour, and for test hypotheses or assumptions. Despite a considerable amount of basic research and theoretical studies, as well as practical case study analyses and test site applications, numerous questions related to the hydrogeological functioning of karst aquifers, such as infiltration mechanisms, flow and storage processes, etc., remain unanswered.

Tracer tests represent an appropriate technique for studying the recharge and transport properties of water and/or contaminants (flow velocities, longitudinal dispersion, retardation, etc.), and catchment delineation (Hauns et al. 2001; Benischke et al. 2007). However, they are usually less frequently applied in karst high plateaus and mountains, since they can be costly and long-lasting. Furthermore, information acquisition is often very difficult or limited, injection and sampling sites may present difficulties of access, and strong tailing effects in the tracer breakthrough may be expected (Massei et al. 2006; Kogovšek \& Petrič 2014; Lauber \& Goldscheider 2014).

In order to investigate the above scientific and practical aspects, and to contribute to better understanding of the behaviour of mountainous karst aquifers, the present study focuses on the hydrogeology of the JavornikiSnežnik karst massif of the Classical Karst in SW Slovenia. The main aim of the study was to obtain more information on groundwater flow within a large karst aquifer and to develop a conceptual model of solute transport characteristics through the mountainous karst aquifer. The initial assessment concerns the effects of the prevailing factors on solute transport within the karst system and flow towards the springs at the aquifer's margins which represent the erosional base. A further aim was to evaluate the protective function of the vadose zone. The final aim was to identify the main underground drainage routes and to delineate the main watershed between the Adriatic and Black Sea basins. An element of more local importance is the enhancement of the hydrogeological characterisation of the Javorniki-Snežnik aquifer. 


\section{STUDY AREA}

\section{HYDROGEOLOGICAL CONTEXT}

The Javorniki-Snežnik massif is a high karst plateau of the Dinaric Karst in south-western Slovenia. The highest parts of the Javorniki are in the central ridge, with elevations of between 600 and $1300 \mathrm{~m}$. Towards the southeast, the plateau transitions into Snežnik, whose summit reaches $1,796 \mathrm{~m}$ a.s.l. The massif is bordered to the west by the Pivka Basin, with elevations of between 500 and $600 \mathrm{~m}$, and to the east and north-east by a system of karst poljes: Babno (760 m), Loško (580 m), Cerkniško (550 $\mathrm{m})$ and Planinsko (450 $\mathrm{m}$ ).

The oldest rocks in the study area are Upper Triassic dolomites, developed in the area between Planinsko Polje and Babno Polje. These build aquifers with fissured porosity, which in places have very poor to medium permeability (Fig. 1). In a narrow belt extending along the poljes, these strata transition to Jurassic limestones and dolomites towards the south and west. The central part of the area is built of Cretaceous rocks, for the most part limestones, in places transitioning to dolomites and breccias. Palaeogenic limestones appear on the southern and western slopes of Snežnik. The carbonate massifs in the western part are surrounded by a belt of poorly permeable Eocene flysch extending from Postojna towards the south. Glacial and fluvio-glacial sediments in the Snežnik area and alluvial sediments in karst poljes and river valleys are of Quaternary age. These build smaller aquifers with intergranular porosity.

Predominantly Cretaceous and, to a lesser extent, Jurassic and Palaeogenic carbonate rocks represent the central karst aquifer of the study area. Groundwater discharges on the northern and eastern margins through springs on the karst poljes, while on the western edge there are several intermittent springs along the Pivka River and, on the south-western edge, karst springs at the contact with flysch near Ilirska Bistrica. On the Croatian side, the large Rječina spring is situated on the southern margin of the aquifer in the hinterland of the city of Rijeka, while on the eastern margin there is the Čabranka spring near the town of Čabar.

The most important springs on Planinsko Polje are the Malenščica, which is used as a drinking water source, and the Unica, which flows from the cave Planinska Jama. Flow rates of the Malenščica range from 1.1 to 11.2 $\mathrm{m}^{3} / \mathrm{s}$, and those of the Unica from 0.2 to $74.8 \mathrm{~m}^{3} / \mathrm{s}$ (Petric 2010). Two large springs, the Rak and the Kotliči, are located in the valley of Rakov Škocjan. The total flows of both were measured in the above-ground section of the Rak stream and ranged from 0 and $72 \mathrm{~m}^{3} / \mathrm{s}$ (Gospodarič $\&$ Habič 1976). There are numerous springs on Cerkniško
Polje, some of which also function as estavelles. On the southernmost edge, the springs feed the Stržen stream, which flows across the polje towards ponors on the north-western margin. Flow data for the Stržen vary considerably since they are only approximate estimates. Jenko (1954) cites flow rates of between 2.8 and $84 \mathrm{~m}^{3} / \mathrm{s}$, while Novak (1964) gives rates of between 0.008 and 33 $\mathrm{m}^{3} / \mathrm{s}$. Slightly further to the west is the Otoški Obrh, an intermittent spring. The intermittent Mali Obrh spring with flow rates of between 0 and $22.5 \mathrm{~m}^{3} / \mathrm{s}$ (Hydrological Daily Data Archive 2016), and the smaller Grajski Izvir, which is a permanent spring, are located on the southwestern edge of Loško Polje.

Several intermittent springs are found on the right bank of the Pivka on the western margin of the karst massif. These are only active in periods of medium and high water levels. The total flow of the Pivka in its upper course is measured at the Prestranek hydrological station and ranges from 0 to $43.3 \mathrm{~m}^{3} / \mathrm{s}$ (Hydrological Daily Data Archive 2016). The most important of the springs on the south-western margin of Snežnik is the permanent Bistrica spring, which is used as a drinking water source. Its flow rates range from 0.2 to $30 \mathrm{~m}^{3} / \mathrm{s}$ (Kovačič 2003). On the Croatian side, the largest spring on the southern margin of the aquifer is the Rječina, which supplies drinking water to the city of Rijeka. The spring has maximum flow rates of up to $120 \mathrm{~m}^{3} / \mathrm{s}$. It dries up in summer, at which time water only discharges through smaller coastal springs in Rijeka (Biondić et al. 1997). To the east, below Snežnik, is the spring of the Čabranka River in the town of Čabar, with flows of between 0.45 and $18.3 \mathrm{~m}^{3} / \mathrm{s}$ (Hydrological Daily Data Archive 2016). Although this spring is probably fed from the area north and north-east of the spring, the geological structure means that the possibility of it being fed from the Snežnik karst massif cannot be excluded.

\section{PREVIOUS TRACER TESTS}

In the study area several tracer tests have been carried out in the past. Thus, the principal and secondary directions of underground flow have been identified (Fig. 1). For the most part, sinking streams in the area of the karst poljes and the surface flow of the Pivka on the margin of the karst massif were selected as injection points. The principal underground flow is in the direction of the springs on Planinsko Polje, while water has also been shown to flow from the Cerkniško Polje area directly towards the springs of the Ljubljanica at Vrhnika (not on the map). In some tests, tracer was injected in the area of the karst massif, but always close to its margin and in the direct catchment area of karst springs (Tab. 1). 


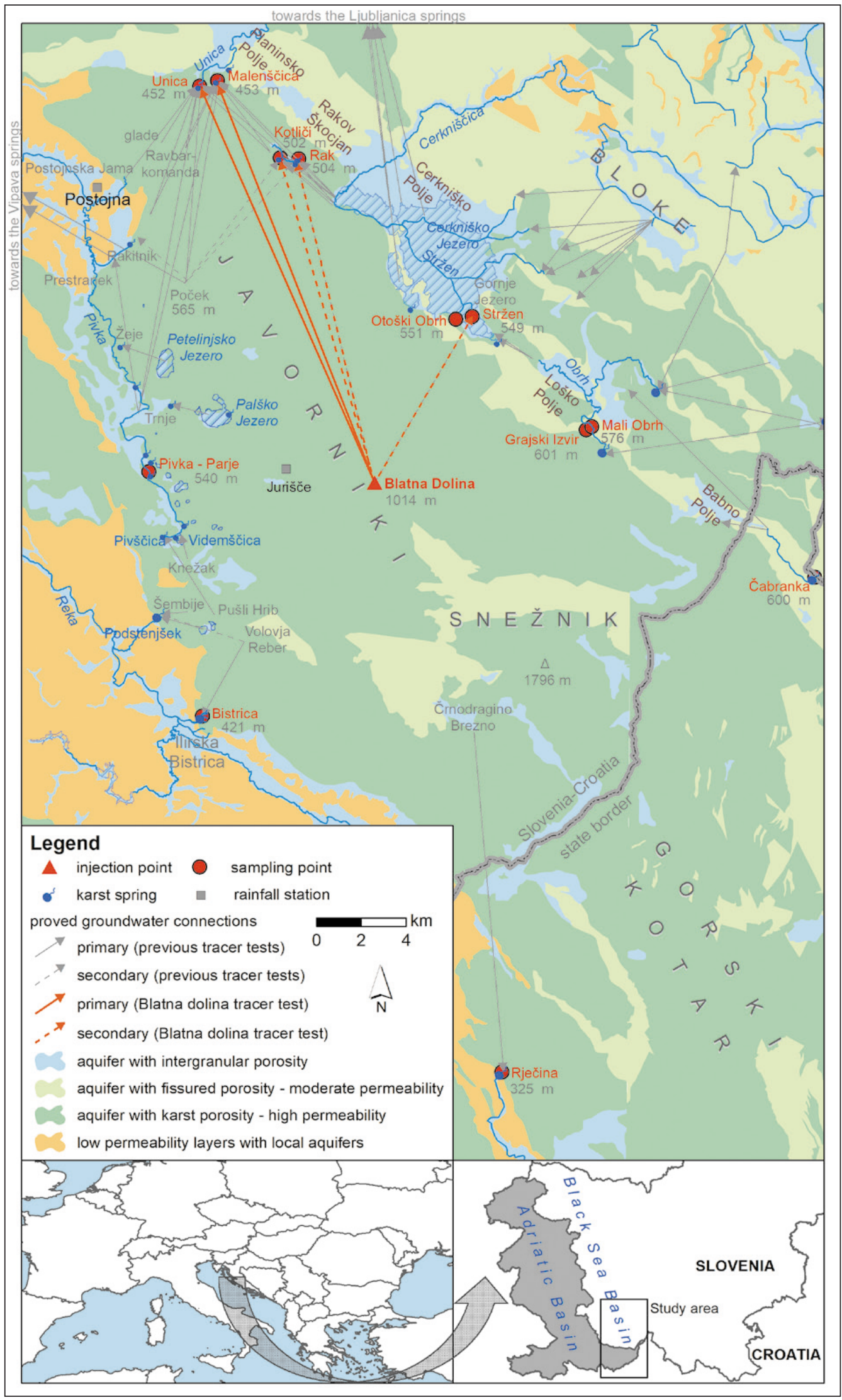

Fig. 1: Hydrogeological map of the area, previously identified underground water connections and sampling points. Tracer flow directions of the recent test with the tracer injection in Blatna Dolina in December 2014 are also shown. 
Tab. 1: Results of previous tracer tests (Habič 1975, 1989; Kogovšek 1999; Prestor et al. 2004; Ravbar \& Goldscheider 2007; Gabrovšek et al. 2010; Ravbar et al. 2012).

\begin{tabular}{|c|c|c|c|c|}
\hline Injection point & Date of injection & Tracer & $\begin{array}{l}\text { Proved connections } \\
\text { (spring) }\end{array}$ & $\begin{array}{c}\text { Linear dominant flow } \\
\text { velocity }[\mathrm{m} / \mathrm{h}] \\
\text { (Recovery) }\end{array}$ \\
\hline Palško jezero & $14 / 11 / 1967$ & coloured spores & Trnje spring & 324 \\
\hline Petelinjsko jezero & $15 / 11 / 1967$ & uranine & Žeje spring & 35 \\
\hline Knežak & $26 / 2 / 1968$ & uranine & Videmščica & 43 \\
\hline brook near Rakitnik & $9 / 8 / 1988$ & rhodamine & Vipava & 14 \\
\hline Pivka near Trnje & 9/8/1988 & uranine & $\begin{array}{c}\text { Unica } \\
\text { Malenščica } \\
\text { Pivka near Prestranek } \\
\text { brook near Rakitnik }\end{array}$ & $\begin{array}{l}18 \\
18 \\
7 \\
7 \\
\end{array}$ \\
\hline Poček & 10/6/1997 & uranine & $\begin{array}{l}\text { Malenščica } \\
\text { Vipava } \\
\text { Unica } \\
\text { Rak } \\
\text { Kotliči }\end{array}$ & $\begin{array}{c}25.8(55 \%) \\
25(26 \%) \\
18 \\
22 \\
25 \\
\end{array}$ \\
\hline Črnodragino brezno & $22 / 5 / 2004$ & uranine & $\begin{array}{c}\text { Rječina } \\
\text { springs in Rijeka }\end{array}$ & $\begin{array}{l}32 \\
14\end{array}$ \\
\hline Šembije & $7 / 3 / 2006$ & sulforhodamin B & Podstenjšek & $23(53 \%)$ \\
\hline Volovja reber & $7 / 3 / 2006$ & eosine & $\begin{array}{l}\text { Podstenjšek } \\
\text { Bistrica }\end{array}$ & $\begin{array}{c}41(1 \%) \\
21(81 \%)\end{array}$ \\
\hline Pušli hrib & $23 / 11 / 2006$ & $\mathrm{LiCl}$ & Pivščica & 95 \\
\hline $\begin{array}{l}\text { Ravbarkomanda } \\
\text { (oil collector) }\end{array}$ & $18 / 11 / 2008$ & uranine & $\begin{array}{c}\text { Unica } \\
\text { Malenščica }\end{array}$ & $\begin{array}{c}9 \\
9.5\end{array}$ \\
\hline glade near Postojna & $2 / 6 / 2009$ & uranine & Unica & $4.4(50 \%)$ \\
\hline
\end{tabular}

Most interesting from the point of view of the study of water flow and solute transport characteristics in high karst aquifers is the tracer test carried out in the area of the Poček military training area in the Javorniki. On 10 June 1997, when the water level was low, $4 \mathrm{~kg}$ of uranine was injected in the rocky bottom of a doline. Samples were then taken in 11 locations over a period of approximately one year (Kogovšek 1999; Kogovšek \& Petrič 2004). The results showed that the greater part of the water flows underground towards the Malenščica spring (55\% of tracer recovered), while a significant part flows towards the Vipava spring (not on the map; $26 \%$ of tracer recovered). The apparent dominant flow velocity in both directions was around $25 \mathrm{~m} / \mathrm{h}$. In this way the main direction of groundwater flow from the karst aquifer of the Javorniki towards springs on Planinsko Polje was identified, while underground flow beneath the flysch of the Pivka Basin towards the Vipava Valley was also confirmed. Tracer also appeared in smaller quantities in other springs on Planinsko Polje and in Rakov Škocjan.

Another important tracer test was carried out in the southern part of Snežnik on 22 May 2004, when $30 \mathrm{~kg}$ of uranine was injected into the stream flow at the bottom of the shaft Črnodragino Brezno (Prestor et al. 2004). Tracer appeared in larger concentrations in the Rječina spring (linear dominant flow velocity $32 \mathrm{~m} / \mathrm{h}$ ), and in slightly smaller concentrations in smaller springs in Rijeka (linear dominant flow velocity $14 \mathrm{~m} / \mathrm{h}$ ).

On the basis of the tracer tests conducted, we may conclude that the general direction of flow in the Javorniki area is towards springs on Planinsko Polje and on towards the springs of the Ljubljanica, which are part of the Black Sea Basin, while in the south-western part of Snežnik flow is towards the springs of the Bistrica and Rječina and smaller springs in Rijeka, which are part of the Adriatic Basin. A peculiarity of this karst area is a bifurcation in the western part of the Javorniki, since flow has been identified both towards the springs on Planinsko Polje (Black Sea Basin) and towards the spring of the Vipava (Adriatic Basin). No older data are, however, available on the drainage of water from the central section, which would enable us to define the location of the Adriatic-Black Sea watershed with greater precision.

\section{MATERIALS AND METHODS}

The main data from the previous tracer tests have been collected (Tab. 1), that only provide information on the underground drainage of the aquifer's margin. Since information on the characteristics of underground flow within the karst massif is lacking, an additional tracer test with injection in the central part of the aquifer was conducted. 


\section{TRACER TEST WITH INJECTION IN THE CENTRAL PART OF THE AQUIFER}

Between September and November 2014 a total of 720 $\mathrm{mm}$ of rain fell at the Jurišče rainfall station on the edge of the Javorniki. Afterwards flooding occurred in the area of the karst poljes and watercourses within the study area. By the beginning of December, conditions had stabilised so much that on 3 December 2014 at 12.00 p.m. a solution of $38 \mathrm{~kg}$ of uranine was injected. The injection took place from the surface at an elevation of $1,014 \mathrm{~m}$ a.s.l. into the 27-metre-deep shaft Brezno 1 in Blatna Dolina and the tracer was washed away with $8.5 \mathrm{~m}^{3}$ of water from a tank belonging to the fire brigade (Figs. 1 and 2).

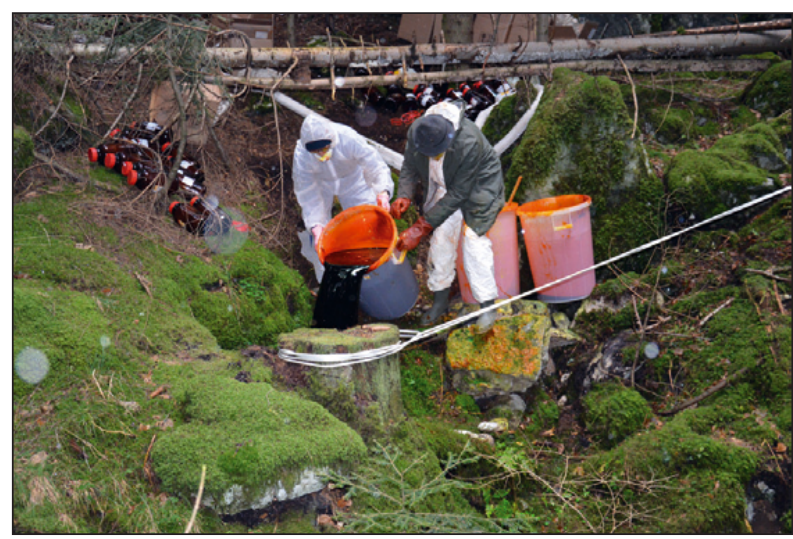

Fig. 2: Injection of uranine into Brezno 1 in Blatna Dolina on $3 t^{h}$ December 2014 (Photo: F. Drole).

Sampling took place at 12 springs in which the appearance of the injected tracer was deemed possible, in view of the geological and hydrogeological conditions (Fig. 1). ISCO 6700 and ISCO 6712 automatic samplers were set up in the Malenščica, Unica (Fig. 3), Otoški Obrh and Rječina springs and the surface flow of the Pivka at Parje, where water already collects from several springs in the upper course of the Pivka.
Manual sampling was organised in the Mali Obrh, Grajski Izvir, Bistrica and Čabranka springs, with occasional sampling in the Kotliči and Rak springs. The Malenščica and Bistrica springs were additionally equipped with a Götschy Optotechnik LLF-M field fluorimeter, which was also set up in the Stržen stream at Gornje Jezero.

The sampling frequency was adapted to hydrological conditions and the results of ongoing analyses. For the most part, sampling took place once a day, while the field fluorimeters recorded data at 30-minute intervals. The first blind samples to determine the natural background were taken in November 2014, while following injection in early December 2014 regular sampling took place in different periods for different springs.

Water samples taken for fluorescence measurements were analysed in the laboratory using a Perkin Elmer LS 45 luminescence spectrometer $\left(\mathrm{E}_{\mathrm{ex}}=491 \mathrm{~nm}\right.$, $\mathrm{E}_{\mathrm{em}}=512 \mathrm{~nm}$, detection limit $0.005 \mathrm{mg} / \mathrm{m}^{3}$ ). Analysis was carried out directly from the samples soon after collection and again later, when any solid particles suspended in the samples had settled.

An Onset HOBO RG3-M data logging rain gauge was installed near the injection point for continuous measurement of precipitation from 3 December 2014 to 21 November 2015. For the subsequent period until the end of sampling on 26 May 2016, daily rainfall data from the Slovenian Environment Agency station in Postojna were used (National Meteorological Service of Slovenia, 2016). In order to calculate the quantity of recovered tracer, it is necessary to have data on the flow rate, so the possibility of obtaining these data was organised for all the observation points. Some springs and watercourses are part of the regular national observation network (e.g., water level measurements in the Stržen - Hydrological Daily Data Archive, 2016), while sondes were set up in others to allow the continuous recording and storage of water level data. The majority of the tracer appeared in
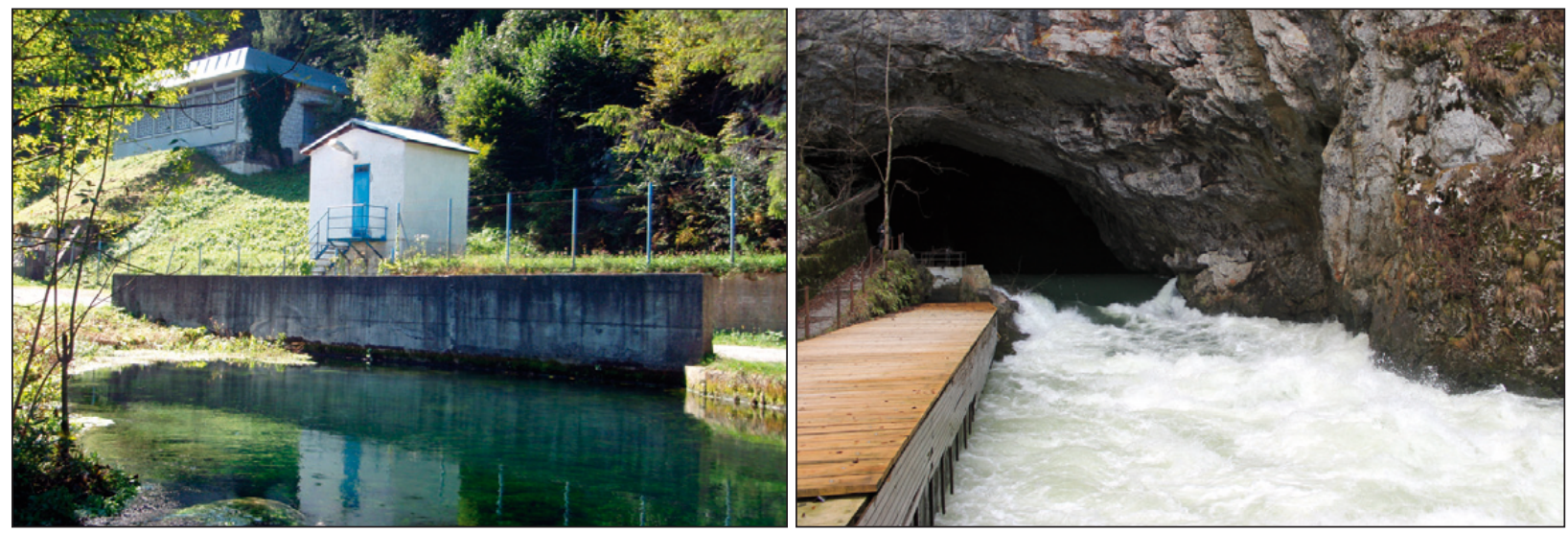

Fig. 3: The Malenščica (left) and Unica (right) springs at the southern border of the Planinsko polje (Photos: M. Petrič, N. Ravbar). 
the Malenščica and Unica springs, so flow rates were determined for both springs for the entire observation period on the basis of collected data on water levels in the Malenščica (ISCO 6700 with 750 Area Velocity Module) and Unica (Onset HOBO water level data logger) and existing flow-rate curves.

\section{DATA ANALYSIS AND COMPARISON}

For assessment of the prevailing effects on solute transport, the results of the Blatna Dolina tracer test were compared to the Poček tracer test that provides the most readily available data (Kogovšek 1999; Kogovšek \& Petrič 2004). Quantitative analysis of tracer test breakthrough curves (BTC) provided basic information on solute transport: the time of first detection $\left(t_{1}\right)$, linear maximum flow velocity $\left(\mathrm{v}_{\max }\right)$, peak transit time $\left(\mathrm{t}_{\mathrm{p}}\right)$, linear dominant flow velocity $\left(\mathrm{v}_{\mathrm{dom}}\right)$, peak concentration $\left(\mathrm{C}_{\mathrm{p}}\right)$ and duration of tracer detection. Recoveries $(\mathrm{R})$ were calculated according to Käss (2004).

The BTC's shapes and magnitudes are directly dependent on tracer type (i.e., the degree of conservative behaviour), injection mode and mass, flow path characteristics (conduits geometry and connectivity, flow length and gradient), hydrological conditions (pre- and post-injection), sampling and analytical procedure, etc. (Hauns et al. 2000; Massei et al. 2006; Morales et al. 2007). To reinforce the comparison, direct data obtained through BTC analysis have been modified (Fig. 4).

The time scale (nt) is adapted to the distance be- tween the injection point and the spring. For the more distant injection point in Blatna Dolina, the time after injection $(\mathrm{t})$ was divided by the factor of distance (ratio between distance from the point of injection to the Malenščica spring for tracing in Blatna Dolina $\left(\Delta \mathrm{d}_{\mathrm{bd}}\right)$ and the Poček area $\left.\left(\Delta \mathrm{d}_{\mathrm{p}}\right)\right)$ :

$$
n t(t)=t /\left(\frac{\Delta d_{b d}}{\Delta d_{p}}\right)
$$

The injected tracer mass and flow rates influence the observed tracer concentrations. Concentration (C) was therefore normalised with regard to the quantity of tracer injected $\left(\mathrm{M}_{0}\right)$ :

$$
N C(n t)=\frac{C(t)}{M_{0}}
$$

Karst conduits form different modes of transport. Residence Time Distribution (RTD) allowed comparison of different flow paths in the system (Jobson 1997). The RTD shows the time the water pulse containing a tracer spends in the system (i.e., tracer cloud passage) and, indirectly, the efficiency of longitudinal mixing processes:

$$
R T D(n t)=\frac{C(t)}{\int_{t i=0}^{t} C(t i) \cdot Q(t i) \cdot d t} \cdot Q(t)
$$

The protective function of the observed transport routes was evaluated according to the following criteria: 1) the normalized time of first tracer detection (nt $)_{1}$, and 2) tracer recovery $(R)$ at the spring were adjusted with regard to the linear distance difference to the spring.

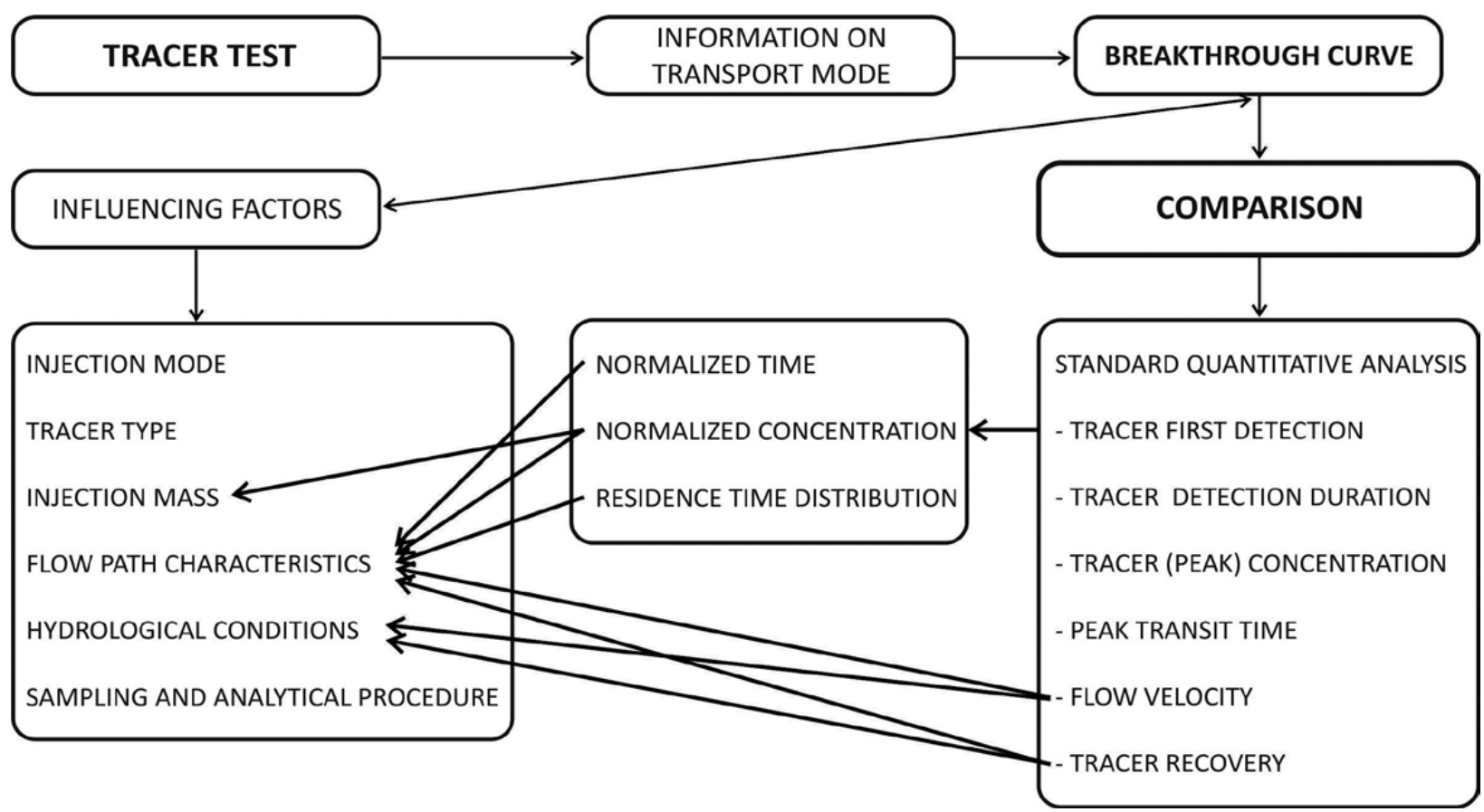

Fig. 4: Flow chart showing factors influencing BTC shape and magnitude, and approaches used in this study to diminish their effects when comparing results of various tracer tests. 


\section{RESULTS}

\section{TRACER TEST WITH INJECTION IN THE CENTRAL PART OF THE AQUIFER (BLATNA DOLINA)}

Following injection on 3 December 2014, the flow rates of the springs declined and rainfall was periodic and light (Fig. 5). In these conditions the first appearance of tracer was recorded on 4 January 2015 in the Unica spring and on 5 January 2015 in the Malenščica spring. Peak concentrations of $0.53 \mathrm{mg} / \mathrm{m}^{3}$ (Malenščica) and $0.44 \mathrm{mg} / \mathrm{m}^{3}$ (Unica) were recorded on 9 January and 8 January 2015 respectively. A total of $30 \mathrm{~mm}$ of rain fell from the time of injection to 9 January. Taking into account the linear distance from the injection point to the springs the linear dominant flow velocity was $22.3 \mathrm{~m} / \mathrm{h}$ towards the Malenščica and $22.5 \mathrm{~m} / \mathrm{h}$ towards the Unica. The first pulse was followed by a slightly less pronounced second pulse after two weeks and an additional $35 \mathrm{~mm}$ of rainfall. A curve showing a uniform rise and fall in tracer concentration formed in both. The first heavy rainfall, which once again pushed the uranine towards the springs, more markedly through the Unica (maximum concentration $0.07 \mathrm{mg} / \mathrm{m}^{3}$ ), only appeared at the end of March 2015 (Fig. 5).

Since a parallel estimate of the percentage of recovered tracer shows that in this initial period a total of only around $17 \%$ of the injected uranine emerged through the Malenščica and Unica springs in the first two significant tracer pulses, it was decided to continue sampling during the period of more pronounced flood pulses in the Malenščica until 23 February 2016 (field fluorimeter measurements until 26 May 2016) and in the Unica until 26 May 2016 (18 months after injection). The appearance of tracer was recorded in each flood pulse, but concentrations did not exceed $0.04 \mathrm{mg} / \mathrm{m}^{3}$ (Fig. 5).

Of the total $38 \mathrm{~kg}$ of injected uranine, approximately $3.2 \mathrm{~kg}$ or $8.4 \%$ emerged through the Malenščica spring during the entire observation period, and $6.9 \mathrm{~kg}$ or $18.1 \%$ through the Unica (Fig. 5). Thus over the course of a year and a half, only a little over a quarter of the injected tracer emerged through the two springs.

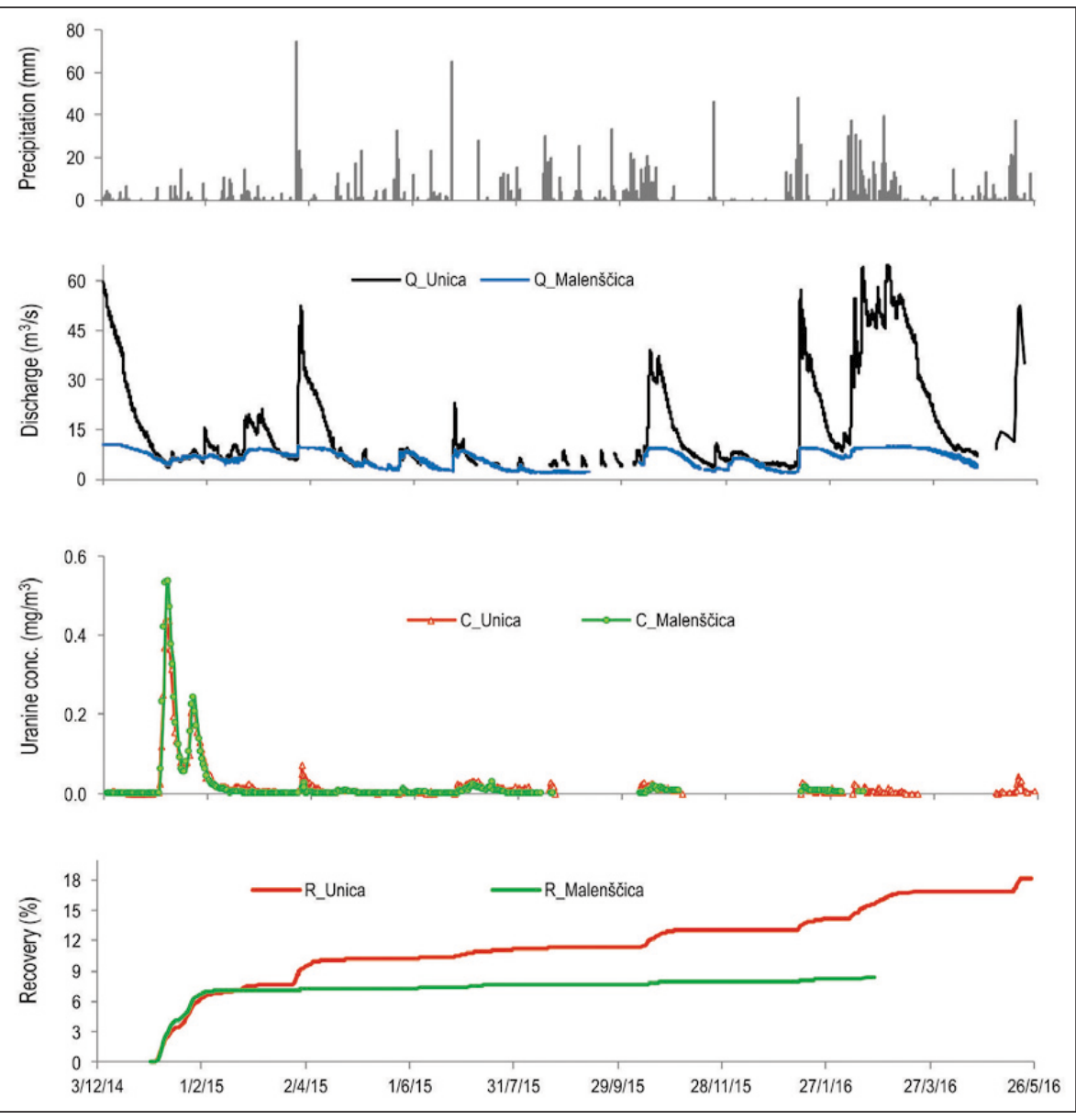

Fig. 5: Daily rainfall in the injection area $(P)$, flow rates $(Q)$ and tracer concentration $(C)$ curves, and percentages of recovered tracer $(R)$ in the Malenščica and Unica springs. 
Uranine was also detected with reasonable certainty in the Kotliči and Rak springs in the valley of Rakov Škocjan (Fig. 6). Since these are two springs in the direct catchment area of the Malenščica and Unica springs, sampling was only carried out there periodically in periods in which, in view of hydrological conditions, it was possible to expect tracer to appear. It is therefore likely that the first tracer pulse in the Kotliči spring was missed, after which a number of subsequent pulses were detected, corresponding with the appearance of tracer in the Malenščica and Unica springs. A maximum value of 0.1 $\mathrm{mg} / \mathrm{m}^{3}$ was measured in the Kotliči spring on 23 January 2015. It is therefore extremely likely that higher values were reached during the first pulse. Regarding the Rak spring, a maximum concentration of $0.145 \mathrm{mg} / \mathrm{m}^{3}$ was recorded on 28 March 2015 (just one sample, possible influence of increased contamination of organic substances). Later, a value of $0.064 \mathrm{mg} / \mathrm{m}^{3}$ was reached in the next major flood pulse at the end of June 2015.

Maximum values of $0.105 \mathrm{mg} / \mathrm{m}^{3}$ were detected by a field fluorimeter in the Stržen spring on Cerkniško Polje on 26 December 2014, when the water level was decreasing. Unfortunately, these values were not verified by the taking of samples for laboratory analysis. Nevertheless, in view of the conditions of declining flow rate following a flood period (low possibility of contamination) and the estimated linear dominant flow velocity of $16.6 \mathrm{~m} / \mathrm{h}$, we consider a connection between Blatna Dolina and the Stržen to be possible.
Up until the end of March 2015, when we stopped taking samples, no uranine had appeared in the Pivka at Parje, on the western margin of the Javorniki. We conclude that there is no direct connection here, although this finding will require verification in the future. Namely, during the tracer test from Poček (Kogovšek 1999) the slowest flow was identified in the direction of the Pivka with the clearest transport of tracer recorded in the biggest flood pulse six months after the injection.

In the other observed springs on Loško Polje and Cerkniško Polje, occasional minor increases of concentrations were detected in individual samples, but these cannot be reliably attributed to the appearance of injected tracer in that they may also be a reflection of the flushing of the natural background and increased contamination with organic substances during larger flood pulses.

Concentrations in the Bistrica and Rječina springs were constantly below the detection limit, so a connection with these two springs is entirely excluded. Therefore, in the given conditions it was confirmed that Blatna Dolina is the part of the Black Sea Basin, which allows us to set the watershed with the Adriatic Basin southern from this location.

One of the purposes of the tracer test, namely to assess the recharge characteristics of the springs on the margin of the karst massif and redefine their recharge areas, was not fully achieved. When the water level is high, waters from the karst massif probably drain towards a number of permanent springs and numerous intermittent

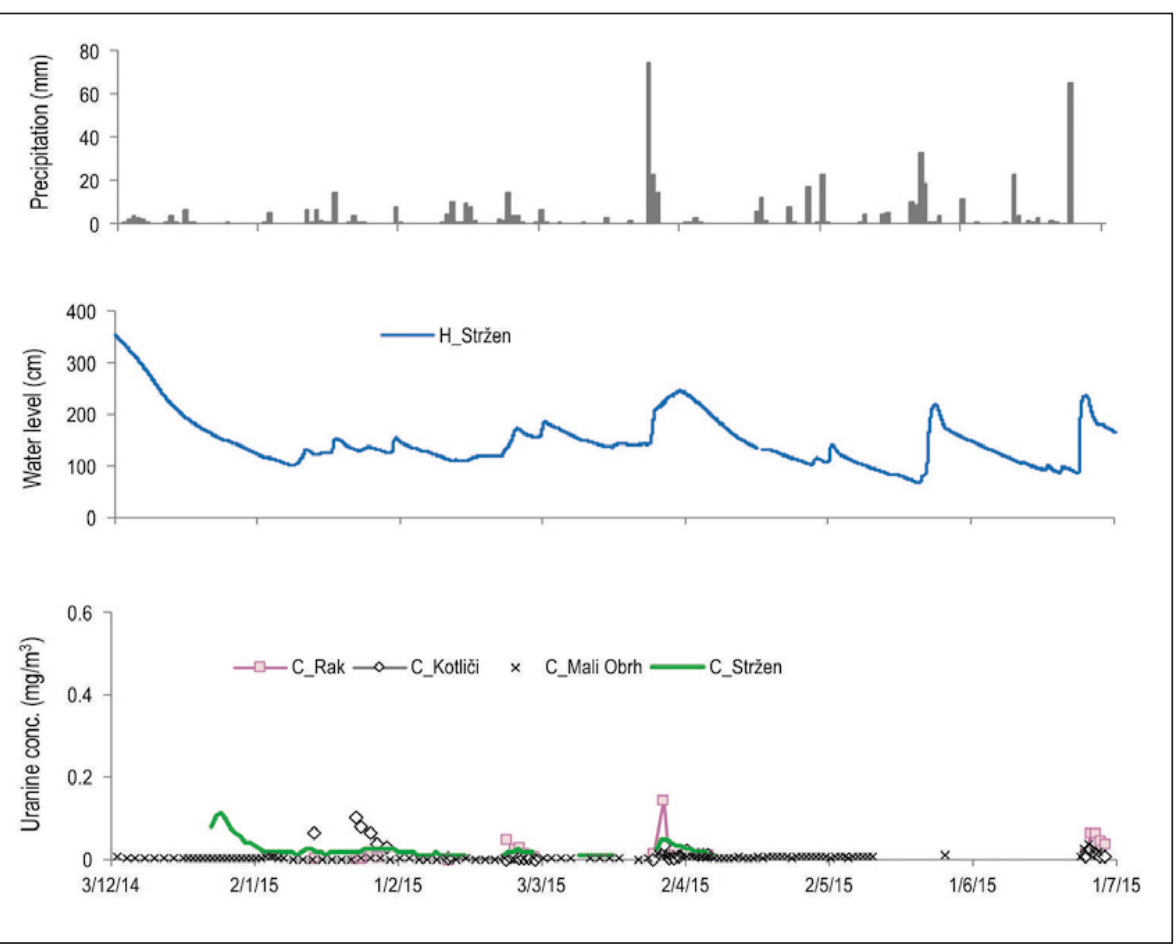

Fig. 6: Daily rainfall in the injection area $(P)$, water level in the Stržen stream $(H)$ and tracer concentration (C) curves in the Rak, Kotliči and Mali Obrh springs and in the Stržen. 
Tab. 2: Overview of the results of the compared tracer tests observed at the Malenščica spring.

\begin{tabular}{|l|l|l|}
\hline Tracer test & Poček & Blatna Dolina \\
\hline Hydrological conditions & Medium-flow & High-flow, recession \\
\hline Injection mode & $\begin{array}{l}\text { Well permeable karren, } \\
\text { flushed with } 11 \mathrm{~m}^{3} \text { of water }\end{array}$ & $\begin{array}{l}\text { Shaft, flushed with } 8.5 \mathrm{~m}^{3} \text { of } \\
\text { water }\end{array}$ \\
\hline Tracer type & uranine & uranine \\
\hline Tracer mass & $4 \mathrm{~kg}$ & $38 \mathrm{~kg}$ \\
\hline No. of sampling sites & 11 & 12 \\
\hline Sampling duration & $\sim 1$ year & $\sim 1.5$ year \\
\hline Tracer recovery $(R)$ & $55 \%$ & $8.4 \%$ \\
\hline Assessed thickness of the vadose zone & $\sim 40 \mathrm{~m}$ & $\sim 400 \mathrm{~m}$ \\
\hline Assessed hydraulic gradient & $\sim 0.008(72 \mathrm{~m} / 9300 \mathrm{~m})$ & $\sim 0.008(161 \mathrm{~m} / 19300 \mathrm{~m})$ \\
\hline Linear maximum flow velocity $\left(\mathrm{v}_{\text {max }}\right)$ & $\begin{array}{l}1^{\text {st }} \text { pulse: } 35.2 \mathrm{~m} / \mathrm{h} \\
2^{\text {nd }} \text { pulse: } 11 \mathrm{~m} / \mathrm{h} \\
3^{\text {rd }} \text { pulse: } 2.6 \mathrm{~m} / \mathrm{h}\end{array}$ & $\begin{array}{l}1^{\text {st }} \text { pulse: } 24.4 \mathrm{~m} / \mathrm{h} \\
2^{\text {nd }} \text { pulse: } 7 \mathrm{~m} / \mathrm{h}\end{array}$ \\
\hline Linear dominant flow velocity $\left(\mathrm{v}_{\text {dom }}\right)$ & $\begin{array}{l}1^{\text {st }} \text { pulse: } 25.8 \mathrm{~m} / \mathrm{h} \\
2^{\text {nd }} \text { pulse: } 9.7 \mathrm{~m} / \mathrm{h} \\
3^{\text {rd }} \text { pulse: } 2.5 \mathrm{~m} / \mathrm{h}\end{array}$ & $\begin{array}{l}1^{\text {st }} \\
\text { pulse: }\end{array} 21.7 \mathrm{~m} / \mathrm{h}$ \\
\hline
\end{tabular}

springs on all sides. Unfortunately, however, hydrological conditions during the initial period of tracing, when the transport of tracer was still quite concentrated, were not suitable for the study of this characteristic. The groundwater level was constantly in a recession and flow towards the lowest-lying springs on Planinsko Polje predominated (with perhaps only a small part towards the Stržen), while the level was too low to recharge the springs in the higherlying parts of the aquifer's margin in the Pivka valley and on Cerkniško Polje and Loško Polje. Later on the tracer cloud was already too attenuated and diluted to confirm with reliability the prediction that part of the groundwater

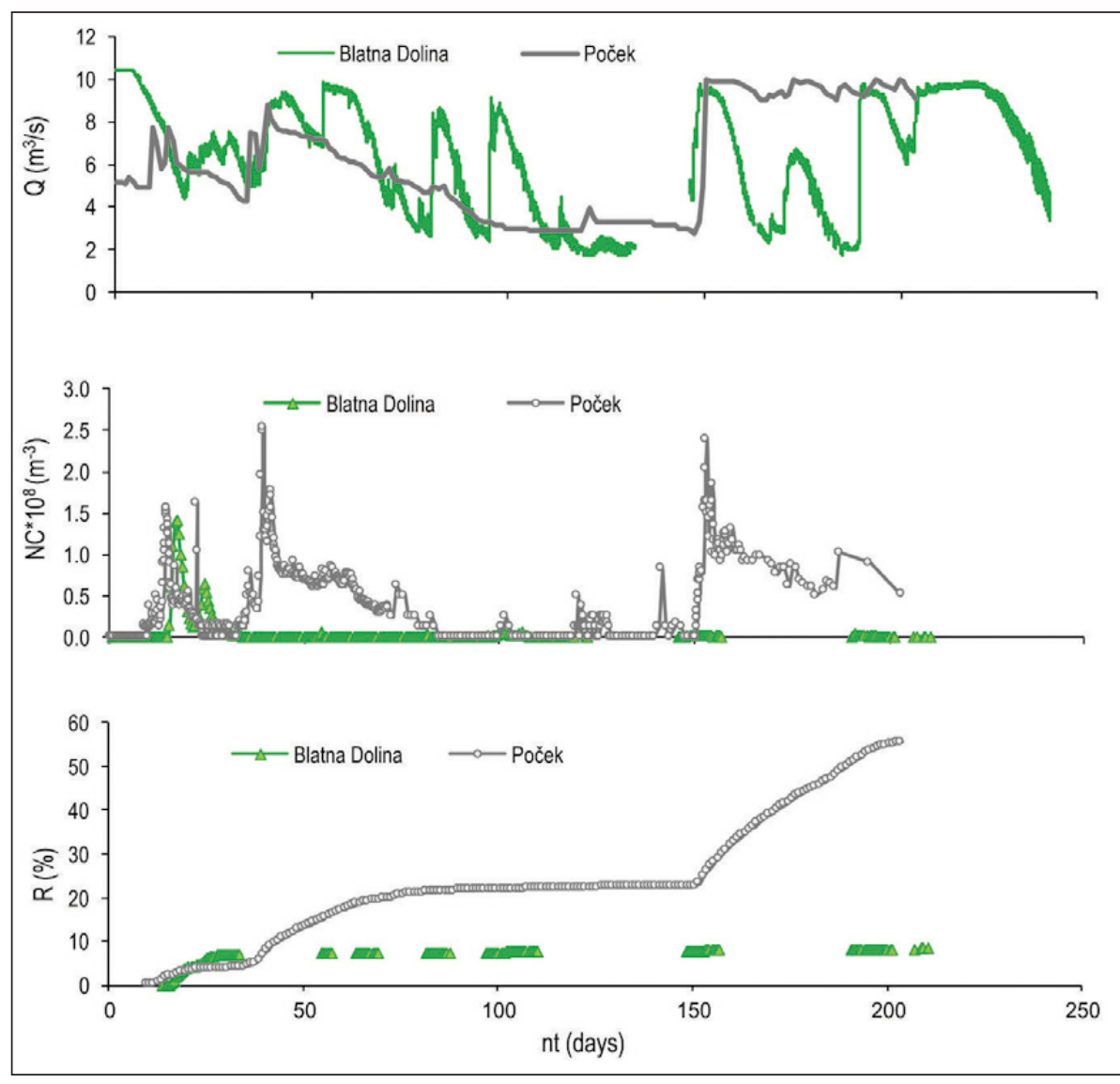

Fig. 7: Comparison of flow rates (Q), normalised concentrations of tracer (NC) and the percentage of recovered tracer $(R)$ in the Malenščica spring during tracer tests from Poček and Blatna Dolina; on the $x$-axis, normalized time ( $n t$ ) is adjusted with regard to the factor of the distance between the injection point and the spring. 


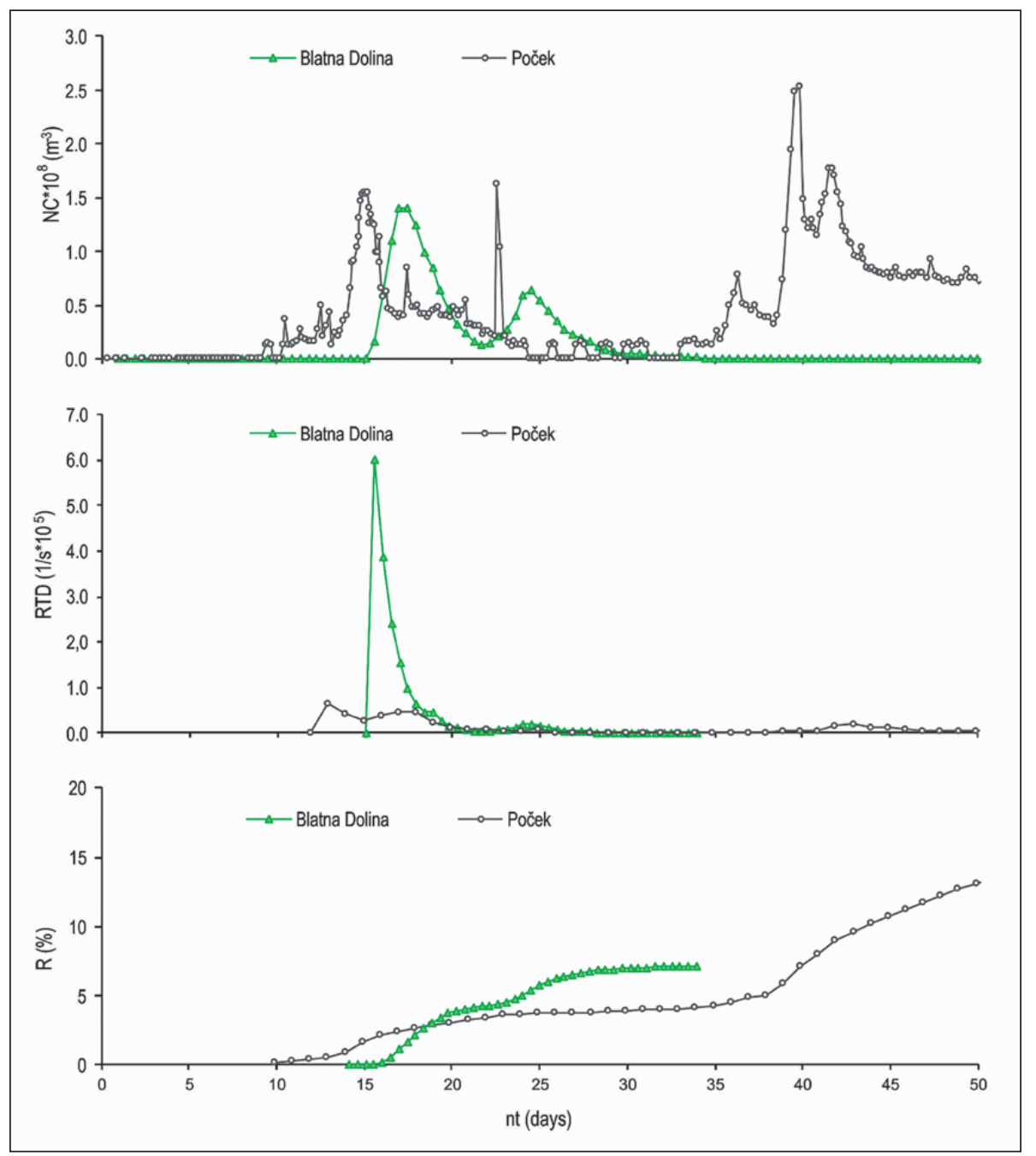

Fig. 8: Comparison of normalised concentrations of tracer (NC), tracer residence time distribution (RTD) and the percentage of recovered tracer $(R)$ in the Malenščica spring for the selected initial period of tracer tests from Poček and Blatna Dolina; on the $x$-axis, normalized time ( $n t$ ) is adjusted with regard to the factor of the distance between the injection point and the spring.

flow is also in the direction of these springs at times when the groundwater level is higher.

Attention should also be drawn to the possibility of groundwater flow towards the springs of the Vipava. Two older tracer tests on the far north-western edge of the massif (Habič 1989; Kogovšek 1999) in fact proved an underground water connection with the Vipava (Fig. 1). Unfortunately, however, the scale of the test, with 12 other sampling points, meant that we were unable to organise sampling there during this test.

\section{COMPARISON WITH A PREVIOUS TRACER TEST (POČEK)}

In both the selected tracer tests, uranine was injected from the surface - in the case of Poček into a highly permeable karst fissure and in the case of Blatna Dolina into a shaft. The appearance of tracer in the Malenščica spring (elevation $453 \mathrm{~m}$ a.s.l.) was compared. The Poček injection point is at an elevation of $565 \mathrm{~m}$ a.s.l., while the Blatna Dolina injection point lies at $1,014 \mathrm{~m}$ a.s.l. The two tests differ significantly in the thickness of the vadose zone ( $40 \mathrm{~m}$ vs $\sim 400 \mathrm{~m})$. However, the hydraulic gradients calculated based on the assessed thicknesses of the vadose zones, are very similar for both cases ( 0.008) (Tab. 2). In the case of Poček, injection took place at a medium water level (flow rate of the Malenščica 4.9 $\left.\mathrm{m}^{3} / \mathrm{s}\right)$. The precipitation that followed $(117 \mathrm{~mm}$ in June and $126 \mathrm{~mm}$ in July) only caused a minor increase in the flow rate (to $7.7 \mathrm{~m}^{3} / \mathrm{s}$ ). More intensive rainfall $(100 \mathrm{~mm}$ in 24 hours) causing higher water levels (flow rates of up to $10 \mathrm{~m}^{3} / \mathrm{s}$ ) did not follow until five months after the injection. The tracer test from Blatna Dolina was carried out during a period of recession following high flow conditions (from 10.4 to $5.4 \mathrm{~m}^{3} / \mathrm{s}$ in a single month). There was no intensive rain in the following four months, and only at the end of March 2015 a precipitation event resulted in a significant increase in the flow rate. Tab. 2 summarises the main results of both tracer tests.

Typical linear dominant flow velocities of the area range between 4.4 and $43 \mathrm{~m} / \mathrm{h}$ (Tab. 1). Comparing tracer 
detection at the Malenščica spring, the linear dominant flow velocities of the two selected tracer tests show typical values $(25.8 \mathrm{~m} / \mathrm{h}$ and $21.7 \mathrm{~m} / \mathrm{h})$.

Both tracer test BTCs have multi-modal pulses (Fig. 7). In case of the Poček test, the shape of the first pulse is narrow, with a dominant single peak and relatively short tailing, while the subsequent pulses form very broad BTCs. After the rapid increase in concentration reaching peaks of $\sim 0.1 \mathrm{mg} / \mathrm{m}^{3}$, on the falling limb, the concentrations stay at a relatively high level $\left(\sim 0.03 \mathrm{mg} / \mathrm{m}^{3}\right)$ for several weeks. In case of the Blatna Dolina test, the first pulse has a continuous two-peaked BTC. It starts with a sudden increase in tracer concentration, reaching its peak of $0.53 \mathrm{mg} / \mathrm{m}^{3}$ four days after the first appearance. In the following period, after the subsequent precipitation events, the BTC displays several secondary peaks that are much less intense because of the high dilution and dispersion, but still recognisable.
To allow comparison between the results of the two tracer tests, the concentration curves were modified (Figs. 7 and 8) according to the distance factor (nt), normalised as a function of tracer mass injected (NC) and expressed as a residence time distribution (RTD). A clear exhibition of multi-modal and generally higher amplitudes of tracer concentration with pronounced tailing effects can be observed in case of the Poček tracer test. Although the test was performed in medium flow conditions, tracer transport towards the spring was more rapid (by 5 adjusted days). Higher tracer recoveries were also achieved. However, if only the first pulses are observed (Fig. 8), the duration of both is almost equal ( 15 adjusted days), and the recoveries are relatively similar. The RTD shows a distinct and very narrow peak in the case of Blatna Dolina, while the curve is a two-peak modal with a lingering tail for a longer period in the case of Poček.

\section{DISCUSSION}

The same tracer (uranine) was used in both tracer tests and injected into the aquifer in a similar manner, namely washing from the surface into, respectively, a highly permeable fracture and a conduit. In the case of Blatna Dolina, the vadose zone is several hundred metres thick, while in the case of Poček it has a thickness of just a few tens of metres. The hydraulic gradient assessed based on the thicknesses of vadose zones is similar for the two cases. The samples were analysed in the same way in the same laboratory. We processed the results obtained by neutralising the effects of differences in the quantity of injected tracer and linear distance in order to be able to compare the transport of the tracer with regard to flow path characteristics. It should be mentioned however, that the two tests were not performed at the same time and at the same location, which means that the uncer-

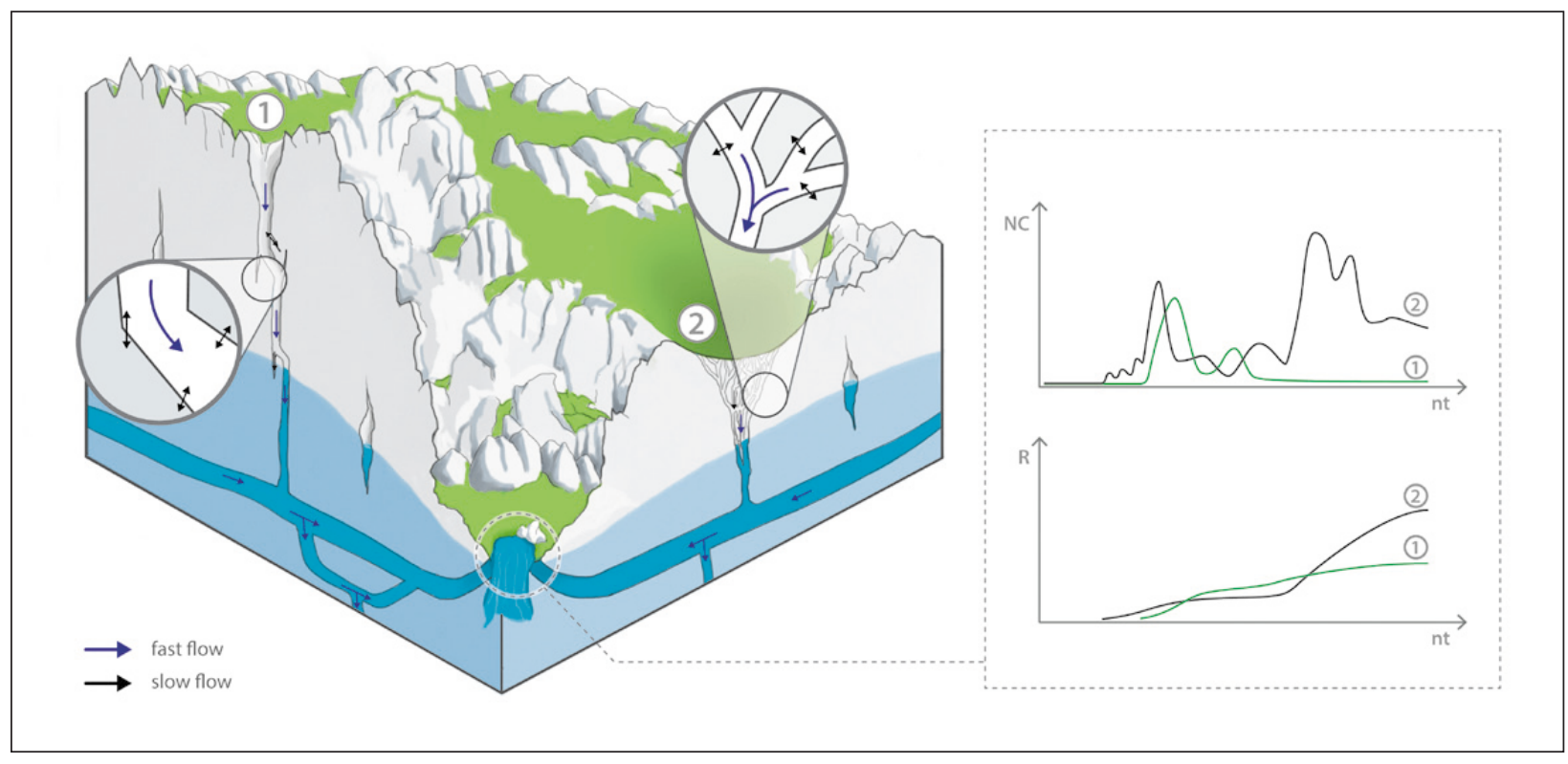

Fig. 9: Conceptual model of flow and solute transport characteristics in mountainous karst aquifers. 
tainties due to the differences in distribution of precipitation events and geological conditions remain. Nevertheless, based on marked differences in the appearance of the tracer at the selected spring, a conceptual model of solute transport through the mountainous karst aquifer was elaborated (Fig. 9).

In the case of Poček, the first precipitation only succeeded in pushing part of the injected tracer (4\%) through the previously largely dry vadose zone to the spring of the Malenščica. The next flood pulse was bigger, resulting in a higher percentage of tracer being pushed through the system (18\%). The largest amount of tracer (33\%) emerged during the third largest autumn flood pulse, which lasted longest and had the highest flow rates. During each pulse the concentrations rose rapidly after the recharge event. Subsequently, the concentrations stayed at a relatively high level on the recession limb for several weeks. Similar observations have been reported by Kogovšek and Petrič (2014) when sampling drip water in a cave and by Goldscheider (2005) when sampling springs. The phenomenon has been explained by the hydraulic interaction between karst conduits and the adjacent rock matrix as the consequence of a recharge event. Storm water causes an increase in hydraulic pressure in the conduits, inducing tracer penetration and temporary storage in adjacent less-karstified areas of the vadose zone. When these areas drain back into the conduits again, the stored tracer slowly flows out of the system (Cornaton \& Perrochet 2002; Perrin et al. 2003).

In the case of Blatna Dolina, tracer was injected at a time of recession following a long flood period. Owing to the favourable previous hydrological conditions, the primary drainage routes in the vadose zone were still hydraulically connected and enabled the continuous transport of part of the tracer (a total of 17\% through the Malenšcica and the Unica), which was pushed into the system by emptying a large quantity of water from a tank during injection, and by the smaller precipitation events that followed. A total of just $65 \mathrm{~mm}$ of rain fell in the two months following injection, and when rainfall did not exceed $15 \mathrm{~mm}$ on individual rainy days until 25 March 2015, resembling the studies mentioned above we infer that also in this case continuous transport through the vadose zone slowed and the greater part of the injected tracer was retained in the less permeable parts of the vadose zone. Although the retained tracer was again pushed by each following rainfall events through the vadose zone, owing to the latter's greater thickness this process is lengthier and more dispersed than in the case of Poček, while the quantity of tracer that reaches the saturated zone is correspondingly diluted. The process continued in similar way after every stronger precipitation event until the end of observation in May 2016. In this period only around a quarter of the injected tracer flowed out through the two springs, while the greater part is percolating gradually through the karst system and draining from it in small quantities during subsequent precipitation events. In view of the findings of studies of the transport of substances through the vadose zone (e.g., Kogovšek \& Petrič 2014), we may conclude that this process will last several more years.

In both tracer tests the first pulses resembled typical flow behaviour in karst aquifers (White 2002). Their shapes and magnitudes corresponded to fast flow in a network of conduits and fissures. In the case of Blatna Dolina, the continuous and uniformly shaped BTCs at the Malenščica and Unica springs indicate that one part of the tracer was transported in a concentrated manner through highly permeable and well-connected conduits. This argument is further supported by the very short residence times of the tracer cloud in the system (RTD). Despite the fact that the tracer test in Blatna Dolina was carried out at a time of high water levels and wet conditions, when higher travel velocities may be expected (Göppert \& Goldscheider 2008; Gabrovšek et al. 2010), tracer appeared in the observed spring relatively later than the tracer from Poček. As the hydraulic gradient is assessed to be very similar for the two cases and a fast flow through a well-permeable conduit was indicated by the BTC shape in the case of Blatna Dolina, this could be explained by the influence of the greater thickness of the vadose zone through which it travelled. Similar conclusion is suggested also by less distinct and more diluted secondary pulses in the case of Blatna Dolina. In the case of Poček the BTC has a rather unbalanced shape with more distinct secondary peaks corresponding to subsequent recharge events. The attenuated and multi-modal peak RTD suggests more diffuse flow paths through a complex system of conduits and fissures.

The relatively small percentage of recovered tracer in the case of Blatna Dolina can be explained by hydrological conditions that are unfavourable for tracing in large karst massifs, the great distances to the springs and the injection method, where there is no connected stream from the surface via which the tracer could drain through the vadose zone of a karst aquifer that is several hundred metres thick. We are also led to this conclusion by the results of other tracer tests conducted in areas with a high vadose zone thickness (e.g., Goldscheider \& Neukum 2010), although some other influences are possible, including characteristics of flow paths, sediments fillings, etc. (e.g., Stevanović 2015).

The described characteristics of the tracer transport in the selected tracer tests support the idea that the thickness of the vadose zone has a decisive effect on increasing retention times of tracer underground and on its disper- 
sion. Despite the fact that the Blatna Dolina test involves infiltration through a wider corrosion shaft and flow through well-connected underground conduits, as well as the hydrologically continuous transport of tracer, we consider that a vadose zone with a thickness of several hundred metres offers greater protection to groundwater and springs from potential contamination than in the case of the tracer test from Poček. In the latter case, the tracer appeared in the observed spring relatively earlier and with a greater percentage of recovered tracer.

\section{CONCLUSIONS}

Although mountainous karst areas are very important aquifers, studies of their functioning are limited by a lack of basic data, poor accessibility and the high complexity of organising research. Such systems nevertheless represent unique areas and by researching them one can get answers to questions about flow and solute transport through karst systems with several hundred metres thick vadose zone.

The study presents the results of a regionally significant tracer test carried out in the area of the JavornikiSnežnik karst plateau (SW Slovenia) with an injection point from the surface in the central part of the unary karst system. In the course of this test we observed 12 springs over a period of a year and a half. The results demonstrated the principal direction of groundwater flow from the central part of the aquifer towards the Malenščica and Unica springs on Planinsko Polje, within the karst catchment area of the Ljubljanica River, and thus part of the Black Sea Basin. In the given conditions, the tracer did not flow southwards to the Bistrica and Rječina springs, which are part of the Adriatic Basin. As a result, we were able to define the position of the Adriatic-Black Sea watershed more precisely.

The comparison with a selected tracer test from the past gave us a better understanding and enabled us to develop a conceptual model of flow and storage mechanisms in karst aquifers. The study confirmed the clear heterogeneity of the karst system: rapid and continuous flow via large karst conduits through the vadose and phreatic zones, and big differences in the dynamics of slow discharge through the karst aquifer, which is mainly affected by precipitation conditions. Outflow (in the ob- served spring) of the tracer injected in the shaft showed a uniformly shaped breakthrough curve, which indicates a direct connection with the part of the water that drains rapidly through the main conduits. The injection of tracer on the karrenfield caused a discharge of tracer in the form of attenuated peaks with an uneven increase and decrease of concentrations, which indicates a gradual and more dispersed percolation of tracer through the aquifer. The study supports the idea that the thickness of the vadose zone has a strong influence on the appearance and dispersal of tracer in this part of the aquifer. However, to clarify the role of the different hydrological conditions in this process a simultaneous tracer test at the two compared locations should be carried out. Additionally, a more detailed geological mapping of the areas studied could improve the understanding of the role of the vadose zone.

The part of the tracer that remains in the system of conduits and fissures can only be pushed gradually on towards the springs by sufficiently heavy rainfall, in a process that can last several years. Owing to the length and complexity of flow paths, this also means the discharge of a more attenuated cloud of injected tracer, and, owing to the greater dilution effects, smaller concentrations in springs that are more difficult to detect. This suggests that the thickness of the vadose zone plays an important role in protecting groundwater and water sources against contamination mainly by dilution and self-cleaning processes. Better understanding of vadose zone effects on flow and solute transport characteristics in mountainous karst aquifers could be a useful tool for improved water management.

\section{ACKNOWLEDGEMENTS}

This study was conducted in the context of the ŠkocjanRisnjak project of the European Fund for Regional Development Cross-Border Cooperation Programme Slovenia-Croatia 2007-2013 and co-funded by the P6-0119
Karst Research programme and by the applied project L17555 Development and application of method for quantity and quality assessment of ground water resources in karst of the Slovenian Research Agency. 


\section{REFERENCES}

Becker, A., 2005: Runoff Processes in Mountain Headwater Catchments: Recent Understanding and Research Challenges.- In: Huber, U. M. et al. (eds.) Global Change and Mountain Regions. Springer Netherlands, pp. 283-295. DOI: 10.1007/1-4020-3508-X.

Benischke, R., Goldscheider, N. \& C. C. Smart, 2007: Tracer techniques.- In: Goldscheider, N. \& D. Drew (eds.) Methods in Karst Hydrogeology. Taylor and Francis, pp. 147-170, London.

Biondić, B., Dukarić, F., Kuhta, M. \& R. Biondić, 1997: Hydrogeological Exploration of the Rječina River Spring in the Dinaric Karst.- Geologia Croatica, 50, 2, 279-288.

Biondić, R., Meaški, H. \& B.Biondić, 2016: Hydrogeology of the sinking zone of the Korana river downstream of the Plitvice lakes, Croatia.- Acta Carsologica, 45, 1, 43. DOI: http://dx.doi.org/10.3986/ ac.v45i1.3057.

Birk, S., Liedl, R. \& M. Sauter, 2004: Identification of localised recharge and conduit flow by combined analysis of hydraulic and physico-chemical spring responses (Urenbrunnen, SW-Germany).- Journal of Hydrology, 286, 1, 179-193. DOI : 10.1016/j.jhydrol.2003.09.007.

Bonacci, O., Oštrić, M. \& T. Roje-Bonacci, 2018: Water resources analysis of the Rječina karst spring and river (Dinaric karst).- Acta Carsologica, 47, 2, 123 137.

Cornaton, F. \& P. Perrochet, 2002: Analytical 1D dualporosity equivalent solutions to $3 \mathrm{D}$ discrete singlecontinuum models. Application to karstic spring hydrograph modelling.- Journal of Hydrology, 262, 1, 165-176. DOI: https://doi.org/10.1016/S00221694(02)00033-1.

Doummar, J., Sauter, M. \& T. Geyer, 2012: Simulation of flow processes in a large scale karst system with an integrated catchment model (Mike She)-Identification of relevant parameters influencing spring discharge.- Journal of Hydrology, 426, 112-123. DOI: 10.1016/j.jhydrol.2012.01.021.

Emblanch, C., Zuppi, G. M., Mudry, J., Blavoux, B. \& C. Batiot, 2003: Carbon 13 of TDIC to quantify the role of the unsaturated zone: the example of the Vaucluse karst systems (Southeastern France).- Journal of Hydrology, 279, 1, 262-274. DOI: 10.1016/S00221694(03)00180-X.

Fehér, K., Kovács, J., Márkus, L., Borbás, E., Tanos, P. \& I. G. Hatvani, 2016: Analysis of drip water in an urban karst cave beneath the Hungarian capital (Budapest).- Acta Carsologica, 45, 3, 213. DOI: http:// dx.doi.org/10.3986/ac.v45i3.3440.
Gabrovšek, F., Kogovšek, J., Kovačič, G., Petrič, M., Ravbar, N. \& J. Turk, 2010: Recent results of tracer tests in the catchment of the Unica River (SW Slovenia).- Acta Carsologica 39, 1, 27-38. DOI: http:// dx.doi.org/10.3986/ac.v39i1.110.

Goldscheider, N., 2005: Fold structure and underground drainage pattern in the alpine karst system Hochifen-Gottesacker.- Eclogae Geologicae Helvetiae, 98, 1, 1-17. DOI : 10.1007/s00015-0051143-z.

Goldscheider, N. \& C. Neukum, 2010: Fold and fault control on the drainage pattern of a double-karstaquifer system, Winterstaude, Austrian Alps.- Acta Carsologica, 39, 2, 173-186. DOI: http://dx.doi. org/10.3986/ac.v39i2.91.

Gospodarič, R. \& P. Habič, 1976: Underground water tracing: Investigations in Slovenia 1972-1975.- Institute for Karst Research, pp. 312, Ljubljana.

Göppert, N. \& N. Goldscheider, 2008: Solute and colloid transport in karst conduits under low- and highflow conditions.- Ground Water, 46, 1, 61-68. DOI: 10.1111/j.1745-6584.2007.00373.x.

Habič, P., 1975: Pivka in njena kraška jezera.- Ljudje in kraji ob Pivki, 41 - 50.

Habič, P., 1989: Kraška bifurkacija Pivke na jadransko črnomorskem razvodju.- Acta Carsologica, 18, 233 264.

Hauns, M., Jeannin, P. Y. \& O. Atteia, 2001: Dispersion, retardation and scale effect in tracer breakthrough curves in karst conduits.- Journal of Hydrology, 241, 3, 177-193. DOI: https://doi.org/10.1016/S00221694(00)00366-8.

Hydrological Daily Data Archive, 2016: Ministry of the Environment and Spatial Planning, Slovenian Environment Agency.- [Online] Available from: http://www.arso.gov.si/vode/ [Accessed 26th May 2016].

Jenko, F., 1954: Vodnogospodarska osnova porečja Ljubljanice.- Projekt nizke zgradbe, Ljubljana.

Jobson, H. E., 1997: Predicting travel time and dispersion in rivers and streams.- Journal of Hydraulic Engineering, 123, 11, 971-978. DOI: 10.1061/ (ASCE)0733-9429(1997)123:11(971).

Kaufmann, G., Gabrovšek, F. \& D. Romanov, 2017: Fracture evolution in soluble rocks: From single-material fractures towards multi-material fractures.- Acta Carsologica, 46, 2/3, 199-216. DOI: http:/dx.doi. org/10.3986/ac.v46i2-3.5135.

Käss, W., 2004: Geohydrologische Markierungstechnik.Borntraeger, pp. 557, Stuttgart. 
Kogovsek, J. \& M. Petric, 2014: Solute transport processes in a karst vadose zone characterized by long-term tracer tests (the cave system of Postojnska Jama, Slovenia).- Journal of Hydrology, 519, 1205-1213. DOI: 10.1016/j.jhydrol.2014.08.047.

Kogovšek, J. \& M. Petrič, 2004: Advantages of longerterm tracing -- three case studies from Slovenia.Environmental Geology, 47, 76-83. DOI: 10.1007/ s00254-004-1135-8.

Kogovšek, J., 1999: Nova spoznanja o podzemnem pretakanju vode $\mathrm{v}$ severnem delu Javornikov (Visoki kras).- Acta Carsologica, 28, 1, 161-200.

Kovačič, G., 2003: The protection of karst aquifers: the example of the Bistrica karst spring (SW Slovenia).Acta cCarsologica, 32, 2, 219-234. DOI: http:// dx.doi.org/10.3986/ac.v32i2.350.

Kübeck, C., Maloszewski, P. J. \& R. Benischke, 2013: Determination of the conduit structure in a karst aquifer based on tracer data: Lurbach system, Austria.- Hydrological Processes, 27, 2, 225-235. DOI: 10.1002/hyp.9221.

Lastennet, R. \& J. Mudry, 1997: Role of karstification and rainfall in the behavior of a heterogeneous karst system.- Environmental Geology, 32, 2, 114-123. DOI: $10.1007 / \mathrm{s} 002540050200$.

Lauber, U. \& N. Goldscheider, 2014: Use of artificial and natural tracers to assess groundwater transit-time distribution and flow systems in a high-alpine karst system (Wetterstein Mountains, Germany).- Hydrogeology Journal, 22, 8, 1807-1824. DOI: 10.1007/ s10040-014-1173-6.

Maloszewski, P., Stichler, W., Zuber, A. \& D. Rank, 2002: Identifying the flow systems in a karstic-fissuredporous aquifer, the Schneealpe, Austria, by modelling of environmental ${ }^{18} \mathrm{O}$ and ${ }^{3} \mathrm{H}$ isotopes.- Journal of Hydrology, 256, 1-2, 48-59. DOI:10.1016/S00221694(01)00526-1.

Massei, N., Wang, H. Q., Field, M. S., Dupont, J. P., Bakalowicz, M. \& J. Rodet, 2006: Interpreting tracer breakthrough tailing in a conduit-dominated karstic aquifer.- Hydrogeology Journal, 14, 6, 849858. DOI: $10.1007 / \mathrm{s} 10040-005-0010-3$.

Morales, T., de Valderrama, I. F., Uriarte, J. A., Antigüedad, I. \& M. Olazar, 2007: Predicting travel times and transport characterization in karst conduits by analyzing tracer-breakthrough curves.- Journal of Hydrology, 334, 1, 183-198. DOI: https:/doi. org/10.1016/j.jhydrol.2006.10.006.

Mudarra, M., Andreo, B., Marín, A. I., Vadillo, I. \& J. A. Barberá, 2014: Combined use of natural and artificial tracers to determine the hydrogeological functioning of a karst aquifer: the Villanueva del Rosario system (Andalusia, southern Spain).- Hydrogeology
Journal, 22, 5, 1027-1039. DOI: 10.1007/s10040014-1117-1.

Mudarra, M. \& B. Andreo, 2011: Relative importance of the saturated and the unsaturated zones in the hydrogeological functioning of karst aquifers: The case of Alta Cadena (Southern Spain).- Journal of Hydrology, 397, 3, 263-280. DOI: https:/doi. org/10.1016/j.jhydrol.2010.12.005.

Müller, M. H., Weingartner, R. \& C. Alewell, 2013: Importance of vegetation, topography and flow paths for water transit times of base flow in alpine headwater catchments.- Hydrology and Earth System Sciences, 17, 4, 1661-1679. DOI: 10.5194/hess-171661-2013.

National Meteorological Service of Slovenia, 2016. Ministry of the Environment and Spatial Planning, Slovenian Environment Agency.- [Online] Available from: http://www.meteo.si/ [Accessed 26th May 2016].

Novak, D., 1964: Hidrogeološka študja slovenskega krasa.Geološki zavod Ljubljana.

Perrin, J., Jeannin, P. Y. \& F. Zwahlen, 2003: Epikarst storage in a karst aquifer: a conceptual model based on isotopic data, Milandre test site, Switzerland.- Journal of Hydrology, 279, 1, 106-124. DOI: https:/doi. org/10.1016/S0022-1694(03)00171-9.

Petrič, M., 2010: Characterization, exploitation, and protection of the Malenščica karst spring, Slovenia: case study.- In: Krešić, N. \& Z. Stevanović (esds.) Groundwater hydrology of springs: engineering, theory, management, and sustainability. ButterworthHeinemann, pp. 428-441, Burlington.

Prestor, J., Urbanc, J., Janža, M., Strojan, M. \& M. Bizjak, 2004: Raziskave mejnih vodonosnikov med Tržaškim in Kvarnerskim zalivom na območju $R$ Slovenije.Geološki zavod Slovenije, Ljubljana.

Pronk, M., Goldscheider, N., Zopfi, J. \& F. Zwahlen, 2009: Percolation and particle transport in the unsaturated zone of a karst aquifer.- Ground water, 47, 3, 361369. DOI: 10.1111/j.1745-6584.2008.00509.x.

Ravbar, N., Barberá, J. A., Petrič, M., Kogovšek, J. \& B. Andreo, 2012: The study of hydrodynamic behaviour of a complex karst system under low-flow conditions using natural and artificial tracers (the catchment of the Unica River, SW Slovenia).- Environmental Earth Sciences, 65, 8, 2259-2272. DOI: 10.1007/s12665-012-1523-4.

Ravbar, N., Engelhardt, I. \& N. Goldscheider, 2011: Anomalous behaviour of specific electrical conductivity at a karst spring induced by variable catchment boundaries: the case of the Podstenjšek spring, Slovenia.- Hydrological Processes, 25, 13, 2130-2140. DOI: $10.1002 /$ hyp.7966. 
Ravbar, N. \& N. Goldscheider, 2007: Proposed methodology of vulnerability and contamination risk mapping for the protection of karst aquifers in Slovenia.- Acta Carsologica, 36, 6, 397-411. DOI: http:// dx.doi.org/10.3986/ac.v36i3.174.

Simsek, C., Elci, A., Gunduz, O. \& B. Erdogan, 2008: Hydrogeological and hydrogeochemical characterization of a karstic mountain region.- Environmental Geology, 54, 2, 291-308. doi:10.1007/s00254-0070817-4.

Stevanović, Z. (ed.), 2015: Karst aquifers - characterization and engineering.- Springer, pp. 692, Cham Heidelberg, New York, Dordrecht, London.

Stevanovic, Z., Kukuric, N., Pekaš, Ž., Jolovic, B., Pambuku, A. \& D. Radojevic, 2016: Dinaric Karst Aquifer-One of the world's largest transboundary systems and an ideal location for applying innovative and integrated water management.- In: Stevanovic, Z., Krešić, N. \& N. Kukuric (eds.), Karst without Boundaries. CRC Press, pp. 1-23, London.
Turk, J., Malard, A., Jeannin, P-Y., Vouillamoz, J., Masini, J., Petrič, M., Gabrovšek, F., Ravba,r N. \& T. Slabe, 2013: Interpretation of hydrogeological functioning of a high karst plateau using the KARSYS approach: the case of Trnovsko-Banjška planota (Slovenia)-. Acta Carsologica, 42, 61-74. DOI: http://dx.doi. org/10.3986/ac.v42i1.640.

Turk, J., Malard, A., Jeannin, P. Y., Petrič, M., Gabrovšek, F., Ravbar, N., Vouillamoz, J., Slabe, T. \& V. Sordet, 2015: Hydrogeological characterization of groundwater storage and drainage in an alpine karst aquifer (the Kanin massif, Julian Alps).- Hydrological Processes, 29, 8, 1986-1998. DOI: 10.1002/hyp.10313. 